\title{
Assessing the consistency of John Calvin's doctrine on human sinfulness
}

Author:
Nico Vorster ${ }^{1}$
Affiliation:
1Faculty of Theology,
North-West University,
Potchefstroom Campus,
South Africa
Correspondence to:
Nico Vorster
Email:
nico.vorster@nwu.ac.za
Postal address:
PO Box 20004, Noordbrug,
Potchefstroom 2522,
South Africa
Dates:
Received: 08 Jan. 2015
Accepted: 13 May 2015
Published: 14 Aug. 2015
How to cite this article:
Vorster, N., 2015, 'Assessing
the consistency of John
Calvin's doctrine on human
sinfulness', HTS Teologiese
Studies/Theological Studies
$71(3)$, Art. \#2886, 8 pages.
http://dx.doi.org/10.4102/
hts.v71i3.2886
Copyright:
@ 2015. The Authors.
Licensee: AOSIS
OpenJournals. This work is
licensed under the Creative
Commons Attribution
License.

Read online:

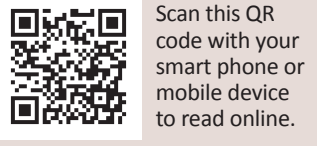

The accusation is often levelled at Calvin that his doctrine on sin is inconsistent, contradictory, deterministic and culpable of making God the Author of sin. This article probes the validity of these accusations by analysing the consistency of John Calvin's doctrine on human sinfulness and by asking whether Calvin's understanding of sinful human nature is theologically valid. In doing so, the investigation keeps in mind the structural make-up of his theology, the rhetorical intent of his utterances and the devices he employs to harmonise possible inconsistencies in his theology. The finding is that characterisations of Calvin's doctrine on sin as deterministic, logically inconsistent and culpable of making God the Author of sin are not well-founded. Factors often overlooked are the dialectical nature of his theological reflection on sin, the chronological evolution of his thought on sin and the fact that he does not regard God and human beings as operating on the same ontological level, though this does not mean that God is not active in creaturely reality. When these factors are taken into account, Calvin's doctrine on sin proves to be fairly consistent and reconcilable with the rest of his theology.

\section{Introduction}

Calvin is well-known for his rather negative and pessimistic, if not denigrating, depictions of human nature. We need only to mention a few passages to prove the point: In his sermon on Genesis 1:26-28, Calvin calls the human being a 'rubbish bin' and a 'slave of Satan' (Calvin 2009:96, SC 11/1.59). ${ }^{1}$ In article 4 of his 1538 Catechism, he depicts the human as inherently 'impure, profane and abominable to God' (Calvin 1972:art 4, CO 5.325) whilst in his commentary on Psalm 8 he refers to human beings as 'poor worms' (Calvin 1845:101, CO 31.80). In other passages, he ranks human beings lower than vermin and insects (Calvin 1574:33, CO 33.104, Calvin 2009:490, SC 11/1.327).

However, before we characterise Calvin's theological anthropology as profoundly pessimistic, if not downright antagonising, we need to note the numerous passages in his works where he celebrates human nature in lofty language. He for instance refers to the human being as the 'brightest mirror' of God's works (Calvin 1845:Ps 8:1, CO 31.88), a 'noble' creature 'above all others' (Calvin 2009:90, SC 11/1.55) and the 'most excellent' of all God's works (Calvin 1847:Gen $1: 26, \mathrm{CO} 23.25,26)$.

These examples of contradicting statements on human nature can probably be explained by attributing it to his rhetorical intent as well as to his understanding of human nature before and after the Fall. Yet, there seem to be other systemic inconsistencies in his doctrine on human sinfulness that are more difficult to harmonise. A few examples will suffice: In certain passages, it seems as if he regards the image of God within humans as being totally annihilated by $\sin$ whilst in other passages he refers to remnants of the image that survived after the Fall (cf. Calvin 1996:47, CO 6.264 with Calvin 1559 Inst: 1.15.4, CO 2.138, 139). At times, he depicts human reason as totally blind and perverted, yet in other passages, he extolls the praiseworthy attributes of natural philosophers and scientists (cf. Calvin 1559 Inst: 1.4.1, CO 2.38-39 with Calvin 1847: Gen 1:16, CO 23.22). Calvin also grounds the event of the Fall in the will and ordainment of God, yet he maintains that God is not the Author of sin.

These seeming contradictions and inconsistencies have led some scholars to depict Calvin's doctrine on sin as deterministic, inconsistent, contradictory and culpable of making God the Author of sin (see Berkhof, 1986:203; Gregory 2012:207, 208; König 2002:127; Taylor 2007:78, 624).

The aim of this article is to assess the logical consistency of Calvin's doctrine on human sinfulness. The first section discusses the theological-rhetorical intent of Calvin's doctrine on sin, the second

1.The Calvin Opera volumes will be referenced as $C O$, noting the relevant volume and page, whilst the Supplementa Calviniana will be referenced as SC, also noting page and volume. English quotations from John Calvin's 1559 Institutes are taken from Calvin (2008). 
his understanding of human bondage and accountability and the third his understanding of the relationship between sin and the imago Dei. The article concludes with a finding on the logical consistency of Calvin's understanding of human sinfulness.

\section{The rhetorical and theological intent of Calvin}

Calvin deliberately develops his theological anthropology, both rhetorically and theologically, to emphasise the sovereignty and glory of God. In order to extol God's glory and goodness, he uses sin and grace as corollaries - the radical, all-encompassing nature of sin demands radical divine grace. By relentlessly stripping the human from all desert, he endeavours to display the purity of God's goodness and grace (Calvin 1559 Inst:2.2.1, CO 2.185; 1996:200, CO 6.372). For Calvin, any notion of human merit in the God-human relationship endangers the profoundness of God's grace because if human '... works are of any avail in attaining salvation, grace is no more' (Calvin 1559 Inst:3.14.5, CO 2.566). This is well illustrated by the following passage in article 6 of his 1538 Catechism (1972, CO 5.335):

This knowledge (of sin), though it strikes man with terror and overwhelms him with despair, is nevertheless necessary for us in order that stripped of our own righteousness, cast down from confidence in our own power, deprived of all expectation of life, we may learn through the knowledge of our own poverty, misery and disgrace to prostrate ourselves before the Lord, and by the awareness of our own wickedness, powerlessness, and ruin may give all credit for holiness, power and salvation to Him.

Calvin's affirmation of the deep-rooted sinfulness of the human race not only serves as a tool to underscore the overwhelming nature of God's glory, sovereignty, omnipotence and goodness, but it also 'compels us to turn our eyes upward' by creating in us a sense of humility and vulnerability (Calvin 1559 Inst:1.1.1, CO 2.33). For Calvin, awareness of sin is of utmost importance for salvation because without a sense of our predicament there will be no desire in us to seek God's mercy and grace (Calvin 1559 Inst:2.2.1, CO 2.185). Only through self-denial can our relationship with God be re-oriented. We cannot aspire to God until we have begun to be displeased with ourselves (Calvin 1559 Inst:1.1.1, CO 2.33).

The downside of Calvin's didactical method is that one can easily be misled by his debasing and denigrating depictions of human nature after the Fall to think that he totally devalues the human; this is, if such passages are not understood within the context of his rhetorical and theological intent to accentuate God's glory. Calvin, in fact, sometimes gets totally carried away by his denigrating description of the human after the Fall (Gerrish 1981:212). The reality, though, is that grace has precedence over sin in Calvin's thinking. Gerrish (1981) states it well:

The restoration of man in Christ has dogmatic precedence even over the doctrine of the original estate, since, so he argues, we know of Adam's blessedness only by viewing it in Christ, the Second Adam. (p. 211)

\section{Sin, bondage and accountability}

When speaking about sin, Calvin often uses the term 'flesh' as a synecdoche. 'Flesh' denotes in Calvin's thinking the human being in 'the fallen condition of sinfulness' before regeneration (Calvin 1859:230, CO 48.111; Miles 1981:314). It is the principle of bondage that governs the whole of human nature and subjects humans to their fallen state through the tyrannical superiority of carnal lusts and desires (Calvin 1559 Inst:3.2.18, CO 2.413). Despite being vitiated by sin, the body as motion devoid of essence plays no role '... in the corruption of the soul, or its own corruption', but is the 'helpless victim' of the 'destructive hegemony of flesh' (Miles 1981:314). Sometimes Calvin uses the term 'body' as synonymous with 'flesh' as indication for the human being's sinful existence. For instance, when he speaks of the body as a prison, he essentially refers to the fallen condition of temporal life and not to the human being's corporeal existence (see Lief 2009:3; Calvin 1859:Rom 6:12, CO 48.111).

For Calvin, the human soul is unique because it possesses a 'unique potential for relationship with God' (Pitkin 2004:353). It is thus not surprising that Calvin also locates the corruption of $\sin$ in the soul (Calvin 1559 Inst:2.1.9, CO 2.193). This does not mean that other parts of the human being are not vitiated by sin, but the soul as the seat of the imago Dei and the source of human actions is the principle location of $\sin$ (Calvin 1559 Inst:2.1.8, 2.19, CO 2.182, 2.184). By locating sin in the soul's faculties of reason and will, Calvin underscores the noetic and volitional aspects of sin (see Pitkin 2004:355-356). He stresses the noetic effects of sin by consistently using the metaphor of 'blindness' to explain sin's hegemony over human reason. Sin 'darkens our understanding' and 'blinds our hearts' (Calvin 1559 Inst:2.3.1, CO 2.209). Human reason is thus cut off from its source of knowledge and deprived of the light of God and therefore becomes 'carnally' minded (Calvin 1559 Inst:2.3.1, CO 2.209). The 'blindness' that sin brings not only corrupts the human mind, but it also leads to idols being created and venerated in the place of God (Calvin 1559 Inst:1.15.12, CO 2.49). The human being is inclined to '... fashion for himself an idol or specter in place of God' (Calvin 1559 Inst 1.15.12, CO 2.49). Actually, reason itself becomes an idol. No longer are human beings content to consult God's will and to confine their reason to the boundaries of God's will, but reason itself is elevated above God (Calvin 1559 Inst 1.15.4., CO 2.51, 2.52). The result is a loss of communion with God. For Calvin, the human's pride and self-adoration is the exact opposite of the image of God that is directed towards reflecting God's virtues and heightening God's glory.

The sin-infected mind is not able to direct the will towards rejecting sin. The will as the volitional principle in the human being is therefore also 'utterly prone to sin' (Calvin 1972:art 5, CO 5.329; Calvin 1845:331, CO 31.206). Yet, Calvin insists that the will is not coerced by $\sin$ in the sense that it is dragged unwillingly into corruption; this would contradict the nature 
of sin. Instead it is bound by sin, which means that, because of its corruptness, it willingly, of its own accord, chooses nothing but evil. The will's corruption is thus self-determined because it sins voluntarily (Calvin 1996:69-70, CO 6.280).

Since sin is self-inflicted, it can in no sense be imputed to God, neither by attributing it to created human nature 2 nor by attributing it to the order of nature (Calvin 1996:47, CO 6.263). Such an inconceivable notion would be an affront to God's goodness (Calvin 2009:98, SC 11/1.55; Calvin 1847:Gen 2:2, CO 2.32). Humans are evil because of their own wrongdoing by which they 'brought wretchedness upon' themselves (Calvin 1996:97, CO 6.263). According to Calvin, sin makes the human liable to condemnation, and this leads to a loss of communion with and participation in God (Calvin 1847:Gen 2:2, CO 2.32). This alienation from God is demonstrated by death, which is God's curse on sin. Death denotes that the human being is cut off from its 'Fountain of life' and thus lives in a state of demise (Calvin 1847:Gen 2:16, CO 2.44).

The question is: How can this curse be imposed on all of humankind because of the sin of their primeval parents? Calvin explains that Adam was not merely a 'progenitor' but 'a root' who, through his corruption, vitiated the whole human race (Calvin 1559 Inst:2.1.6, CO 2.180; see Denlinger 2009:242). ${ }^{3}$ Sin is, therefore, systemic in nature. When Adam sinned, he '... transmitted the contagion to all his posterity' (Calvin 1559 Inst:2.1.6, CO 2.180). Adam's posterity is liable to God's punishment, not because Adam's sin pertains to them, but because they are infected by the same corruption (Calvin 1559 Inst:2.1.6, CO 2.180). The question Calvin faced was: How can human beings be held liable by God if their actions are necessitated by their nature?

In his commentary on Genesis, he posits that God created human beings with a free will to choose between good and evil. Free will does not entail that the human being can act outside of God's decree. For Calvin, divine determinism and humanity's free choice are not contradictions. Human freedom is compatible with God's eternal decree because God's providence does not destroy human deliberation but God wills that the human act freely (Marko 2010:49, 50). Tragically, humans abused their freedom by choosing to be independent from God and to depart from God's perfect wisdom, resulting in bondage to $\sin$ (Calvin 1847:Gen 2:9, CO 23.38).

2. Calvin vehemently opposed the idea of the Manicheans that evil is part of the substance of the hupposed the inea of the Manicheans that evil is part of the substance of the huma (human's own fault (see Calvin 1996:47, CO 6.263)

3.Calvin shifted the debate on the transmission of sin from Augustine's biological categories to noetic categories. For Calvin, sin is first of all moral and religious blindness, not something transmitted through sexual concupiscence as posited by Augustine. Furthermore, for Calvin, humanity shares a corporate solidarity in sin and death because our being is corrupt. The mere fact that we are born corrupted makes us guilty before God. It is thus important to note that Calvin does not distinguish as some federalists do, between the human's original guilt in Adam and the actua perversion of sin that gradually follows through time. Perversion and guilt are closely perversion of sin that gradually follows through time. Perversion and guilt are closely interconnected. The perversion of sin brings guilt whilst guilt brings perversion. In any case, Calvin did not regard the debate on the nature of the transmission of sin as important. In his Commentary on Psalm 51:7, Calvin states that the question on the transmission of sin is not important and that it is not sensible to enter into such
mysterious discussions (see Calvin 1845:Gen 51:7, CO 31.514).

4.According to Calvin, the root of humanity's defection from God was infidelity and a desire to exalt themselves against God by acquiring illicit knowledge (see Calvin 1845:Gen 3:6, CO 23.60, 61; 1559 Inst:2. 1.4, CO 2.188).
In creating the human being with a free will, God not only allowed for the possibility that the human could revolt against him (Calvin 1847:Gen 3:6, CO 23.59, 60), but in fact, God ordained that they be tempted (Calvin 1847:Gen 3:1, CO 23.54):

Adam did not fall without the ordination and will of God, I do not take it as if sin had been ever pleasing to Him, or as if simply wished that the precept which he had given should be violated. So far as the fall of Adam was the subversion of equity, and of well constituted order, so far as it was contumacy against the Divine Law Giver, and the transgression of righteousness, certainly it was against the will of God; yet none of these things render it impossible that, for a certain cause, although to us unknown, he might will the fall of man.

In his Institutes, Calvin uses stronger terms. God not only 'foresaw the Fall' but actually 'arranged' it (Calvin 2008 Inst:3.23.7, CO 2.704).

This position of Calvin is due to his unrelenting belief in God's omnipotent providence; nothing can occur outside of God's will. Though Calvin consistently maintains the position that God is not the Author of sin, he struggles to reconcile this with his belief in God's omnipotence that entails that everything happens according to God's will and eternal counsel. The following quotation reveals the inner tension that Calvin experienced on the matter (Calvin 1847:Gen 3:1, CO 23.54):

It offends the ears of some, when it is said that God willed this fall; but what else I pray is the permission of Him, who has the power of preventing, and in whose hand the whole matter is placed, but his will?

Calvin holds that even though God willed the temptation, he cannot be regarded as the Author of sin since humans sinned voluntarily (Calvin 1847:Gen 3:7, CO 23.64). Two questions naturally arise: Firstly, how can God ordain something but not be regarded as complicit in the outcome of the action? Secondly, how can human nature sin voluntarily if humans' actions are necessitated by an ordination of God?

Calvin addresses this conundrum by employing the Scholastic distinction between absolute and relative necessity. In contrast to Luther's view of necessity as compulsion, Calvin supports the notion of relative necessity. It entails that, though God controls all things, it is fortuitous to us. From a divine perspective, all things are determined, but from a human perspective, the future is contingent. Marko (2010) elucidates well what the Reformers understood under contingency:

An absence of necessity, not to be equated with chance, but rather to be understood as the free operation of secondary causes. In a contingent circumstance, an effect results from clearly definable causes, though the effect could be different, given an entirely possible and different interrelation of causes. In short, a contingent event or thing is a nonneccessary event or thing that either might not exist or could be other than it is. (p. 40)

That which God has determined is thus from a human point of view not absolutely necessary (Calvin 1559 Inst:1.16.9, 
CO 2.152; also see Lane 1981:72-90; Pitkin 2004:365). Even though human beings sin 'necessarily', they do not sin by absolute necessity, because they are not coerced by external compulsion. Necessity does not mean that sin is committed without 'wilful and evil intent' (Calvin 1559 Inst:2.4.1, CO 2.224; see Pitkin 2004:365). Calvin (2008 Inst:2.3.5, CO 2.213) further states the following:

Man, since he was corrupted by the fall, sins not forced or unwilling, but voluntarily, by a most forward bias of the mind; not by violent compulsion, or external force, but by the movement of his own passion; and yet such is the depravity of his nature, that he cannot move and act except in the direction of evil. If this is true, the thing not obscurely expressed is, that he is under a necessity of sinning.

Closely related to the argument on necessity is the twocauses argument that Calvin borrowed from Thomas Aquinas to explain why God cannot be regarded as the Author of evil. In order to avoid dualism, classical theology distinguished between the causa prima, the causa secundae and the causa finalis. The causa prima refers to God as the first cause of all things who, through his eternal decree, takes the initiative in the creation of all things. There can be no other causa prima than God. All other causes that emanate from the first cause are relative to the first cause and are themselves always taken up in a wide network of other causes (see Van de Beek 2014:359). This does not mean that God operates in a deistic fashion, because the first cause is always in an indirect manner involved in the secondary cause whilst second causes execute the order determined by first cause (see Van de Beek 2014:359, 369). For instance, when a carpenter (first cause) uses a hammer (second cause) to hit a nail into a split piece of wood to fix it (final cause), the second cause does not function in isolation from the first cause, but the first cause uses the second cause as an instrument to cause a chain of causal events. The second cause thus stands in an instrumental relation to the first cause. The causa prima and the causa finalis can be regarded as pure in nature, but the same does not hold for the secunda causa, which is instrumental, relative and contingent in nature.

Applied to the relationship between God and sin, the twocauses argument entails that, though God is the principal cause, he is not the immediate Author of all actions since secondary causes that flow from the primary cause have an integrity of their own and can be regarded as contingent (Engel 1988:135-136). The question is: How should we regard evil? Is it a cause of its own? Thomas Aquinas held that evil is privatio boni because it has no causa finalis of its own. Evil is accidental in nature, it derives from the chain of secondary causes, and it affects the chain of events, but it has no meaning of its own nor can it change the causa finalis determined by God (see Van de Beek 2014:369-370).

Calvin employed the two-causes argument to state that, since God is not the '... Author of evil but the first cause, human beings remain free from compulsion' (Engel 1988:135). It furthermore enabled him to posit that human beings 'held captive under bondage of sin' possess no free choice while also maintaining that, even though sin is 'not in our power to avoid', it is 'nonetheless voluntary' (Calvin 1996:37, CO $6.255) .^{5}$

Calvin is adamant that nothing can happen or exist outside of God's will. God does not merely allow sin because he is not a passive God, but he actively willed the Fall because he always acts as the causa prima. All events are thus causally related to each other and therefore always have meaning (see Van de Beek 2014:361). Yet, Calvin also maintains that we need to make a distinction between what God wills and what he commands. God willed that Adam sinned, but he did not command Adam to sin. Adam is thus guilty of his own voluntary actions (Inst 1.18.4, CO 2.172; Van de Beek 2014:363).

The objection might be levelled against Calvin' s theory that God still acts immoral if he sets in motion a primary cause that might result in a distorted secondary event. However, for Calvin, God acts in this way in order to preserve the integrity of creation and human beings. God does not use humans as if they are inanimate creatures that can neither act nor choose (Calvin 1559 Inst:1.17.4, CO 2.157). Secondly, God's decrees as first causes are good because the causa finalis of his decree is good and to the benefit of the whole of creation. If God did not will a Fall, there would not be the opportunity for God to show his love towards humankind through Jesus Christ and for human beings to know God through Christ. The secondary actions of Adam thus ought to be seen in relationship to God's causa finalis in Christ (Calvin 1559 Inst: 1.18.3, CO 2.170-171). Thirdly, Calvin does not regard God and human beings as operating on the same ontological level (Calvin 1559 Inst:1.17.2, CO 2.157). The logic that applies to human conduct thus cannot necessarily be applied to God. Since God and human beings operate on different ontological levels, the distinction between primary and secondary causation is a necessary construction for Calvin and allows him to state that God is absolutely sovereign while humans are at the same time totally responsible for their actions. God's omnipotence entails that he has the power to establish the contingency of second causes, and since second causes are contingent in nature, humans are culpable of their sins. Even if God is the origin of evil, in a human sense, that evil is good because it serves our best interests (see Van de Beek 2014:390).

The Westminster Confession of Faith (Beeke \& Ferguson 1999:46-56) followed Calvin in relying heavily on the twocauses distinction to affirm both God's absolute sovereignty and the responsibility of humanity for its sin. Article 3.1 states:

God from all eternity, did by the most wise and holy counsel of His own will, freely and unchangeably ordain whosoever comes

5.In his reply to Pighius, Calvin uses the example of a sick person. People might become sick of their own accord. Hence, at some point, it must have been possible for the sick for them not to become ill, but when they then indeed do become ill, it is no longer possible for them to undo the sickness caused by an unrestrained life. In the same manner, humankind sinned voluntarily but through the voluntary sin became entangled in the bondage of the sin. Humankind's bondage in sin is not attributable to God but to human nature because the origin of the bondage is due to an initial voluntary act (see Calvin 1996:144, 145, CO 6.335) 
to pass: yet so, as thereby neither is God the author of sin, nor is violence offered to the will of the creatures, nor is the liberty or contingency of second causes taken away, but rather established.

In article 5.2 the Westminster Confession comments as follows on the providence of God:

Although in relation to the foreknowledge and decree of God, the first cause, all things come to pass immutably and infallibly; yet by the same providence, $\mathrm{He}$ ordereth them to fall out, according to the nature of second causes, either necessarily, freely, or contingently.

In article 5.4, the Confession proceeds to use the same distinction to state that, though the Fall is part of the 'ordering and governing' of God, its sinfulness proceeds only from the creature.

Since sin and evil falls within the will of God, Calvin is able to state that God uses the sins of wicked people to serve his purpose. They are like saws in his hand that move, turn and direct them where he wills, yet their doing of evil originates from them and is to be imputed only to them (Calvin 1996:48, 49, CO 6.264). God is not the Author of evil when he uses the ungodly to accomplish and execute his works through them, but he is rather a '... wonderfully expert craftsmen who can use bad tools as well' (Calvin 1996:40, CO 6.258).

Admittedly the relationship between God's goodness and omnipotence and human accountability for $\sin$ is a deep mystery that defies human explanation. We indeed risk overstepping the boundaries of human reason by trying to explain this mystery. Yet, I would venture to argue that the criticism against Calvin's theology that it turns God into the Author of sin does not sufficiently take into account Calvin's two-causes argument and his view that God and human beings operate on different ontological levels. Calvin's contribution, and for that matter Thomas Aquinas', exists therein that they overcome dualism and maintain the sovereignty of God by not recognising evil as an independent power that exists alongside God. Evil is accidental in nature, it cannot function outside of God's will, and it eventually serves God's destination with his creation. By using the twocauses argument, Calvin succeeded in maintaining a distance between God and the world of the second causes. Van de Beek (2014:395) rightly notes that modern theologians often err by locating God and his actions in the field of the second causes. God then becomes a player in history, a second cause himself.

\section{Sin and the imago Dei}

According to Van Vliet (2009:253), 'Calvin's description of the imago Dei matures over time, but the core of his definition remains fairly consistent'. Calvin '... changed his mind about certain aspects of the imago Dei, clarified other matters, and added things which were previously lacking' (Van Vliet 2009:256). Calvin's initial position regarding sin's effect on the imago Dei is that sin totally destroys the image of God in the human (see Engel 1988:57-59). In the 1536 edition of his Institutes, he simply states that the image of God was 'effaced' by sin. In his 1538 Catechism, he describes the image as 'wiped' out whilst in the 1539 edition of the Institutes he makes no effort to alter the position (Calvin 1536 Inst:16, CO 1.28; Catechism:art 4, CO 5.325). Pighius entered into debate with Calvin on this point, accusing Calvin of turning human beings into 'brute beasts' (1996:38, CO 6.257). In his response, Calvin calls attention to his rhetorical intent. He states that his teaching on sin serves to remind human beings that they should blame themselves and not put the blame elsewhere when they find the root of evil in themselves. Secondly, they must give credit to God when doing good deeds. Thirdly, only God in his omnipotence is able to restrain and bridle sin. The believers should thus find comfort in God's omnipotence, not in their own capacity to fight evil (Calvin 1996:38-39, CO 6.257). By proclaiming the total annihilation of the imago Dei, Calvin's intention was clearly not to dehumanise human beings. His initial position was that, despite the loss of the image, God preserves the humanity of the human person through his common grace. Human dignity is not dependent upon the survival of the imago Dei in us but upon God upholding our status as human beings. Later on, he seemingly realised the untenable nature of this position. If sinful human beings are still recipients of God's common grace, they should be able to mirror God in some sense. Some vestige of the image must therefore have survived.

Possibly as a result of his debate with Pighius, Calvin restated his rhetoric on the total destruction of the imago Dei. The challenge he faced was to reconcile his doctrine on sin with his anthropology in a manner that does not diminish God's radical grace by ascribing too much to human capacity. Conversely, he also needed to avoid dehumanising the human being to such a degree that virtuous behaviour and a shared social ethics becomes impossible.

Calvin's restated position was that the imago Dei is totally corrupted but not destroyed. Corruption entails that, after the Fall, depravity is diffused through all parts of the human being's soul and body (Calvin 1847:Gen 3:6, CO 23.59). It does not '.. reside in one part only, but pervades the whole soul, and each of its faculties' (Calvin 1847:Gen 3:6, CO 23.63). Human beings are thus divested from all the distinguishing gifts they once possessed and are '... reduced to a condition of wretched and shameful destitution' (Calvin 1845:Ps 8:5, CO 31.172). What remains after the Fall, according to Calvin, is only a miserable 'ruin' that reminds us of our original excellence in the same manner that a ruin is reminiscent of the original beauty of a building (Calvin 1845:Ps 8:5, CO 31.172; 2009:489, SC 11/1.326). In defining the extent of our corruption, Calvin is careful to allow no avenue for semi-Pelagianism. The 'ruins' of the imago Dei works in us a longing for restoration in Christ; it is in no sense a sufficient tool to attain salvation through our own efforts. In order to be restored, the human being needs a 'new nature' of a supernatural origin (Calvin 1559 Inst:2.1.9, CO 2.183). Calvin (2008 Inst:1.15.4, CO 2.139) phrases this argument as follows: 
Although we grant that the image of God was not utterly effaced and destroyed in him, it was, however so corrupted that any thing which remains is fearful deformity, and therefore our deliverance begins with that renovation which we obtain from Christ.

Though utterly depraved, the 'ruin' of human nature still possesses some remnants of the imago Dei, which gives us a perception of the 'liberality' that God displayed when creating humanity (Calvin 1845:Ps 8:9, CO 31.95). These remnants remind us of God's great mercy, but they also create in us an awareness of sin and the utter misery in which we find ourselves (Calvin 2009:91, SC 11/1.55). Torrance (1957:101) rightly observes that Calvin turns the original meaning of the imago Dei into its opposite: It now actually becomes a symbol of disgrace. Yet, by recognising the survival of remnants of the imago Dei in us, Calvin stresses that sin does not dehumanise the human being (see Gerrish 1981:219). In his sermon on Genesis 9:3-7, Calvin states that, despite the Fall, humanity, though depraved, still possesses the image of God. We must therefore 'honour and revere' God's image in our fellow human beings, and human life must be held sacred (Calvin 2009:733, SC 11/1.476). He (Calvin 2009:745, SC 11/1.485) then proceeds to state the following:

Although that image is almost completely destroyed in us, we see clearly how God still shows it in our neighbours and distinguishes them from the brute beasts and demonstrates they possess a nobility and dignity above all creatures.

It might be argued that Calvin does not go far enough to preserve the humanitas of the human being after the Fall since he ascribes a very limited role to the remnants of the image that survive. After all, what is noble and dignified about a 'ruin'? To be fair, we need to realise that Calvin is primarily concerned with the issue of salvation, not with human dignity. From a salvational point of view, the 'remnants' serve no purpose; the image is basically obliterated. Secondly, Calvin defines good works in a very narrow sense. Only works aimed at glorifying God are regarded by him as virtuous (Calvin 1559 Inst:3.14.3, CO 2.565). Beneficial and humanitarian deeds for the sake of humanity or other interests do not qualify as good works since they are driven by wrong inner intentions (Calvin 1559 Inst:3.14.3, CO 2.565). Calvin's references to the 'remnants' as almost destroyed should therefore not be misunderstood as indicating a low view of natural human ability. In fact, in some passages, he uses quite generous language to rejoice in the admirable skills and abilities of 'ungodly' humans as displayed in the arts and sciences (cf. Calvin 1559 Inst:2.2.25, 2.2.16, CO 2.206, 2.199) Gerrish (1981) states it well:

What he (Calvin) was concerned to establish was, not that man is utterly bad, but that the taint of sin vitiates even his best and leaves no corner of his life unblemished. And Calvin tried to demonstrate this thesis, in turn, with respect to both man's intellectual and his moral achievements. (p. 219)

Calvin carefully delineates his position on the nature of the 'remnants' that survive after the Fall by distinguishing between the natural and supernatural gifts of the imago Dei. ${ }^{6}$ The supernatural gifts pertain to those heavenly gifts 'above nature' that are 'sufficient for the attainment of heavenly life' such as faith, pure knowledge of God, love of God, charity towards the neighbour, righteousness and holiness. In contrast, the natural gifts relate to matters of the earthly realm such as intelligence, art, the ability to discern between good and evil, the creation of social bonds, practicing politics and economics and possessing a sense of becoming and of shame (Calvin 1559 Inst:2.2.12, CO 2.196; Calvin 1845: Ps 8:5, CO 31.91). The effects of sin on the two categories of gifts are dissimilar. The natural gifts were corrupted by sin. Though not destroyed, they are severely weakened and impaired (Calvin 1559 Inst:2.2.12, CO 2.196). The supernatural gifts, in contrast, were totally 'withdrawn' by God, which makes humans incapable of salvaging themselves (Calvin 1559 Inst:2.2.12, 2.2.13, CO 2.196, 2.197). ${ }^{7}$ Consequently, the 'remnants' only refer to the vestiges of the natural gifts that the human originally possessed, not to spiritual gifts. This distinction enables Calvin to preserve the humanitas of all people, including unbelievers, and to sustain the possibility of a shared social ethics ${ }^{8}$ whilst affirming the doctrine of salvation through faith in Christ alone without any human merit (see Gerrish 1981:213).

Calvin attributes the loss of the supernatural gifts to God's punishment. Alienated from their Creator, humanity's being was stripped by God of the 'excellent gifts' with which humanity was previously 'adorned' (Calvin 2009:95, SC 11/1.57). He (Calvin 1847:Gen 3:6, CO 23.63) states quite explicitly that humanity's corruption is not due to some process of natural degeneration, but, to God's will:

For the human race has not naturally derived corruption through his descent from Adam; but that result is rather to be traced to the appointment of God, who, as he had adorned the whole nature of mankind with most excellent endowments in one man, so in the same man he again denuded it.

Calvin's position can be ascribed to his firm belief that human beings live, move and exist in God and that nothing occurs outside of God's will. This position of Calvin might be regarded by some as ambiguous. If the corrupted nature of the imago Dei is due to God denuding human beings from their excellent gifts, is God not made instrumental in the sinful

6.Calvin took over the distinction between supernatural and natural gifts from Scholasticism but modified it to serve his theology. He, for instance, did not share the Schoolmen's optimism regarding the ability of natural reason to comprehend the human telos.

7.The following quotation provides a clear example of Calvin's understanding of the difference between natural and supernatural gifts: 'we have one kind of intelligence of earthly things, and another of heavenly things. By earthly things, I mean those who do not relate to God and his kingdom, to true righteousness and future blessedness, but have some connection with the present life, and are in a manner confined within its boundaries. By heavenly things, I mean the pure knowledge of God, the method of true righteousness, and the mysteries of the heavenly kingdom. To the former belong matters of policy and economy, all mechanical arts and liberal studies. To the latter belong the knowledge of God and of his will, and the means of framing the life in accordance with them' (Calvin 2008 Inst:2.2.13, CO 2.197).

8.Calvin's understanding of the possibility of a shared social ethics after the fall is illustrated by the following quotation: 'Since man is by nature a social animal, he is disposed, from natural instinct, to cherish and preserve society; and accordingly we see that the minds of all men have impressions of civil order and honesty. Hence it is that every individual understand how human societies must be regulated by it is that every individual understand how human societies must be regulated by
laws, and also is able to comprehend the principles of those laws' (Calvin 2008 laws, and also is able
Inst:2.2.13, CO 2.197). 
effects of the Fall? How can human beings be held liable for sin if God denudes them of the very qualities they need in order to know and serve God? Calvin's (Calvin 1845:Gen 3:6, $\mathrm{CO} 23.63$ ) answer is that our supernatural endowments are gifts, and God has the right to take away gifts whenever he wants:

Now if any should object that it is unjust for the innocent to bear the punishment of another's sin, I answer, whatever gifts God had conferred upon us in the person of Adam, he had the best right to take it away, when Adam wickedly fell.

Calvin's argument is that, if Adam truly had a free will and the full ability to obey God, God is just in holding Adam and those he represented liable for their inevitable disobedience since it was their own guilt that prompted the punishment. Since God has the right to punish, he also has the right to choose the instrument of punishment.

Calvin ascribes the preservation of some remnants of the natural gifts in humankind to God's common grace. ${ }^{9}$ In doing so, he avoids creating an opportunity for any teaching that denies the total and radical nature of sin. For Calvin, the survival of 'remnants' of the image is not a result of some innate capability within the human that was capable of surviving the onslaught of $\sin$, but it is wholly due to God who sustains the 'remnants' and acts for the 'common benefit of mankind' (Calvin 1559 Inst:2.2.16, CO 2.199): Actually there is nothing praiseworthy that does not proceed from God (Calvin 1559 Inst:2.2.13, CO 2.197). Hence, though radical and comprehensive, sin does not involve an 'ontological break' with God because God keeps affirming his gracious intentions towards his creation (Torrance 1957:83, 92). Common grace is the result of God, with creation in mind, keeping his original intentions (Calvin 1847:Gen 3:6, CO 23.63). Calvin states the need for God's common grace thus: Had God not spared us, our revolt would have carried along with it the entire destruction of human nature (Calvin 1559 Inst:2.2.17, CO 2.200).

The Spirit is the primary instrument in God's bestowal of common grace. Whilst not working faith in all men, the Spirit 'fills, moves and invigorates' all people and provides them with a sense of right and wrong with the aim of preserving order (Calvin 1559 Inst:2.2.16, CO 2.199). With regard to the earthly realm, no '... man is devoid of the light of reason' (Calvin 1559 Inst:2.2.13, CO 2.197). In fact, the human mind '... is still adorned and invested with admirable gifts from its Creator' (Calvin 1559 Inst:2.2.15, CO 2.198). Calvin deduces from Romans 2 that the natural law is naturally 'engraved' on the minds of all people, even Gentiles (Calvin

9.Calvin himself does not use the term common grace, but the idea is present in his works. The term 'common grace' (algemeene gratie) was developed most extensively by the Dutch theologian Abraham Kuyper, who utilised Calvin's distinction between different forms of grace to develop a social doctrine that differentiates between various social spheres governed by different forms of grace. Whilst both kinds of vace grace come from the one God, they differ in both reach and effect. Specific grace is a salvational kind of grace whereas common grace has a universal scope and a preservative, providential and non-salvational effect. God displays his special grace through the Holy Spirit that regenerates believers by working faith in them whils he uses his common grace to preserve the created order amidst the effects of sin. God's preservation of creation exists therein that he governs in his providence 'the counsels and wills of men' as to 'move exactly in the course which he has destined' (Calvin 1559 Inst:1.16.8, CO 2.152).
1559 Inst:2.2.22, CO 2.203). This is displayed in the ability of Gentiles to distinguish between right and wrong, having a '... sense of judgment' and maintain 'some integrity among themselves' (Calvin 2009:745, SC 11/1.485). This natural knowledge of right and wrong, though, is not sufficient for salvation. It bears no relationship to the renewal of the human being in Christ but only serves the maintenance of the earthly realm (Calvin 1559 Inst:2.2.13, CO 2.203).${ }^{10}$ As a matter of fact, Calvin relates the remnants of natural knowledge directly to his doctrine on double predestination. The remnants serve as a justification for God's punishment since they render all sins inexcusable (Calvin 1559 Inst:2.2.22, 3.14.3, CO 2.203, 2.565). Thus, because all people have enough natural knowledge to distinguish between right and wrong, the non-elect are liable for punishment.

\section{Finding}

We now turn to the question posed at the beginning of the article: Does Calvin provide a consistent doctrine on human sinfulness? To give a fair assessment, we need to take account of some mitigating factors.

A defining feature of Calvin's doctrine on human sinfulness is the dialectical nature of its construction. Because Calvin uses the sinfulness of human nature as a foil for the radical nature of God's grace, his theology is simultaneously profoundly pessimistic about humanity and pervasively optimistic. From one point of view, '... we are nothing, and from the other how magnified' (Calvin 1559 Inst:3.2.25, CO 2.418). That is why Calvin can call human beings at once 'vermin' and God's most 'noble' creatures (Calvin 1574:Job 2:1, CO 33.127-152; 2009:90, SC 11/1.55). Yet, it is important to note that, in Calvin's theology, God's grace eventually overwhelms human sinfulness. ${ }^{11}$ This fundamental position of Calvin can easily become obscured, and his theological anthropology can undeservedly be made out to be 'pessimistic' if the dialectical nature of his theological anthropology is overlooked.

Secondly, it is important to note that Calvin's theology evolved through time. He consistently enhanced and amended his doctrines in response to the criticism he received and the debates in which he was involved. Notably, in response to the criticism of Pighius, Calvin restated his earlier position on the destruction of the image after the Fall to one of a total corruption of the image. This is probably the most drastic change of position that occurs in his doctrine on sin. This change in position provided Calvin's theology with greater coherence and helped to integrate his doctrine on sin with his doctrines on the two kingdoms of God and God's special and general grace.

10.Calvin states that human beings are 'blinder than moles' when it comes to knowledge of God as he is in himself and in relationship to us (Calvin 1559 Inst: 2.2.18, CO 2.200). Van Drunen rightly notes that Calvin's use of the concept of natural law must be understood in relationship to his two-kingdoms doctrine. In natural law must be understood in relationship to his two-kingdoms doctrine. In the two kingdoms, natural law serves both a negative and positive function. With regard to the earthly realm, the function of natural law is essentially positive. It sets forth standards for 'legal and political endeavors'. In the heavenly realm, its function is negative; it makes us aware of our sins and leaves us guilty before God
(see Van Drunen 2004:505).

11. His placing the doctrine of $\sin$ in the second book of the 1559 Institutes, which deals with soteriology, is evidence of this. 
The device that Calvin applies most to explain the dialectic between human beings' total corruption and their ability to act morally despite sin is the distinction between the natural and supernatural. With regard to the natural realm, Calvin affirms human freedom. He extols the natural gifts of fallen man in various disciplines such as the sciences, arts, economics and politics. The corruption of the imago Dei does not entail that humans are dehumanised and capable of nothing but sin. Humanity's natural gifts endure because of God's common grace and universal providence that preserves creation and humanity despite sin. Humans still have the natural law encrypted in their minds to give them a sense of right and wrong. They still possess an earthly wisdom that allows them to seek the good. Yet, with regard to the supernatural realm, Calvin allows no room for human freedom. Human beings are not able to turn to God by themselves, to conquer sins through their own efforts, to attain salvation based on merit, to attain heavenly wisdom. Calvin stresses the inability of human beings with regard to the supernatural to such an extent that he sometimes gives the impression that human existence is fallen in all areas, totally incapable of any good or virtue. As a matter of fact, overzealous rhetoric often leads Calvin to making strong statements that are not reconcilable with his theology as a whole. This peculiar characteristic of Calvin's writings makes his works difficult to interpret and demands that interpreters pay special attention to the various contexts within which he utters his words.

Contextual and rhetorical considerations, however, do not explain all of the seeming inconsistencies in Calvin's doctrine. The element of Calvin's doctrine on sin that his critics find the most concerning is his insistence that the human being is responsible for sin despite the fact that God ordained the Fall. How can a good God ordain a Fall, and how can a just God hold humans responsible for acts that they commit out of necessity? The argument is that an individual or person that is a principal author of an action by instigating, arranging, ordaining or permitting an action cannot be absolved from being culpable of the consequences that might ensue. Calvin attempts to resolve the contradiction by calling on the free-will argument, the notion of relative necessity and the Scholastic two-causes argument. Underlying these arguments is Calvin's understanding that God and human beings operate on different ontological levels. The norms that are applicable to human conduct are thus not necessarily applicable to God. God's omnipotence furthermore entails that he is indeed capable to establish the contingency of second causes in order to preserve the integrity of creaturely reality. Calvin's explanation of the relationship between divine sovereignty and human responsibility is complex but intelligible. It allows him to avoid dualism, to emphasise the accidental nature of sin, to uphold the transcendence of God and to preserve the unity of history that finds its consummation in Christ.

In conclusion, we might state that the doctrine of $\sin$ is probably the most difficult theological theme to deal with. Though we see the reality of evil and sin all around us, its origin and nature is, as Calvin himself contended, a mystery.
Any reflection on sin is therefore bound to be plagued by impasses, ambiguities and inconsistencies. Yet, theology cannot escape reflecting on sin and its origins because it is so fundamentally part of human nature. Calvin made a valiant and plausible attempt to explain the mystery of sin and the relationship between divine sovereignty and human responsibility. Though his understanding of sin might be challenged and criticised, his doctrine is fairly consistent and his arguments warrant serious consideration.

\section{Acknowledgements Competing interests}

The author declares that he has no financial or personal relationships which may have inappropriately influenced him in writing this article. The National Research Foundation (NRF) provided funding for this research. The views stated in this article do not necessarily reflect the views of the NRF.

\section{References}

Beeke, J.R. \& Ferguson, S.B., 1999, Reformed confessions: Harmonized with an annotated bibliography of reformed doctrinal works, Baker Books, Grand Rapids, MI.

Berkhof, L., 1986, Christian faith, Eerdmans, Grand Rapids, MI

Calvin, J., 1574, Sermons on Job, transl. A. Golding, Georgij Bishop, Londini.

Calvin, J., 1845, The Book of Psalms, transl. J. King, Calvin Translation Society, Edinburgh.

Calvin, J., 1847, Commentaries on the first book of Moses called Genesis, transl. J. King, Calvin Translation Society, Edinburgh.

Calvin, J., 1859, Commentary on the Epistle of Paul the apostle to the Romans, transl. J. Owen, Calvin Translation Society, Edinburgh.

Calvin, J., 1972, Catechism or institution of the Christian religion, transl. L.W. Battles, Pittsburgh Theological seminary, Pittsburgh, PA.

Calvin, J., 1996, The bondage and liberation of the will, transl. A.N.S. Lane \& G.I. Davies, Baker Books, Grand Rapids, MI.

Calvin, J., 2008, Institutes of the Christian religion, transl. H. Beveridge, Hendrickson Publishers, Peabody, MA.

Calvin, J., 2009, Sermons on Gen 1-11, transl. R.R. McGregor, Banner of Truth Trust, Edinburgh.

Denlinger, A., 2009, 'Calvin's understanding of Adam's relationship to his posterity: Recent assertions of the reformers "federalism" evaluated', Calvin Theological Recent assertions of thal $44,226-250$
Journal

Engel, M.P., 1988, John Calvin's perspectival anthropology, Scholars Press, Atlanta, GA.

Gerrish, B., 1981, 'Mirror of God's goodness: Man in the theology of Calvin', Concordia Theological Quarterly 45(3), 211-222.

Gregory, B., 2012, The unintended reformation: How a religious revolution secularised society, Harvard University Press, Cambridge, MA.http://dx.doi.org/10.4159/ harvard.9780674062580

Kőnig, A., 2002, God waarom lyk die wêreld so? Kan ons sê God is in beheer, Lux Verbi, Wellington.

Lane, A.N.S., 1981, 'Did Calvin believe in free-will?', Vox Evangelica 12, 72-90.

Lief, J., 2009, 'Is Neo-Calvinism Calvinist? A Neo-Calvinist engagement of Calvin's "two kingdoms" doctrine', Pro Rege XXXVII(3), 1-10.

Marko, J.S., 2010, “"Free choice" in Calvin's concepts of regeneration and moral agency: How free are we?', Ashland Theological Journal 41-60.

Miles, M., 1981, 'Theology, anthropology and the human body in Calvin's Institutes of the Christian religion', Harvard Theological Review 74(3), 303-323.

Pitkin, B., 2004, 'The protestant Zeno: Calvin and the development of Melanchton's anthropology', The Journal of Religion 84(3), 345-378. http://dx.doi. org/10.1086/383451

Taylor, C., 2007, A secular age, Harvard University Press, Belknap, Cambridge, MA.

Torrance, T., 1957, Calvin's doctrine of man, Eerdmans, Grand Rapids, MI.

Van de Beek, A., 2014, Een lichtkring om het kruis: Scheppingsleer in christologisch perspectief, Meinema, Zoetermeer.

Van Drunen, D., 2004, 'The context of natural law: John Calvin's doctrine of the two kingdoms', Journal of Church and State 46(3), 503-525. http://dx.doi. org/10.1093/jcs/46.3.503

Van Vliet, J., 2009, Children of God: The Imago Dei in John Calvin and his context, Vandenhoeck \& Ruprecht, Göttingen. http://dx.doi.org/10.13109/9783666569180 